\title{
Effects of Fungicides on Penetration by Pyricularia oryzae as Evaluated by an Improved Cellophane Method
}

\author{
Fujio Araki and Yukio MiYagi \\ Biological Research Center, Nihon Nohyaku Co., Ltd., \\ Kawachi-nagano, Osaka 586, Japan
}

(Received May 12, 1977)

\begin{abstract}
Effects of several fungicides, active against rice blast, on the penetration by Pyricularia oryzae were studied in vitro by using cellophane film as a model of plant cell walls. The fungus penetrated the film by infection pegs emerging from appressoria (appressorial penetration) and partly by hyphal tips (hyphal penetration). Some fungicides known to be nontoxic against spore germination, appressorium formation, and mycelial growth affected selectively the appressorial penetration but not hyphal one. Effects of fungicides on appressorial penetration seem to be useful to explain the disease-control activity of fungicides.
\end{abstract}

\section{INTRODUCTION}

Fungitoxicity of chemicals in vitro has been conventionally determined on either spore germination or mycelial growth in the field of agricultural fungicides as well as industrial ones. However, the blast-control fungicides such as alkylthiocyanate compounds, ${ }^{12}$ pentachlorobenzyl alcohol (PCBA), ${ }^{2)}$ and 4,5,6,7tetrachlorophthalide (tetrachlorophthalide) ${ }^{3}$ showed practically no activities on either spore germination or mycelial growth of Pyricularia oryzae, but specifically inhibited the fungal penetration into rice plant. This suggests that evaluation method in vitro for agricultural fungicides should be reexamined from the plant pathological aspect.

The mode of action of PCBA was demonstrated in vitro by using cellophane film as a model of plant cell walls. ${ }^{4}$ ) In this experiment cellophane film was in most cases penetrated by hyphal tips (hyphal penetration) and partly by infection pegs emerging from appressoria (appressorial penetration), and these two modes of penetration were equally evaluated. Although the cellophane method proposed by $\mathrm{Oku}$ et al. ${ }^{4)}$ has been employed for other chemicals, ${ }^{5-7)}$ it seems to be unsuitable to consider the two different penetrations equivalent in view of ordinary appressorial penetration on host plants.

In the present paper, the cellophane method was improved to enhance much more appressorial penetration than hyphal one and the difference between two modes of penetration was elucidated through studying the effects of fungicides on the penetration by $P$. oryzae.

\section{MATERIALS AND METHODS}

\section{Fungus Preparation}

A strain of rice blast fungus, Pyricularia oryzae coded as $\mathrm{P}-2$, was supplied from the National Institute of Agricultural Sciences. It was grown on $\mathrm{V}-8$ juice-agar medium $(\mathrm{V}-8$ juice $100 \mathrm{ml}, \mathrm{CaCO}_{3} 1.8 \mathrm{~g}$, agar $22 \mathrm{~g}$, and deionized water $1000 \mathrm{ml}$ ) in a Petri dish at $25^{\circ} \mathrm{C}$ under a fluorescent lamp. Spores from 7-day culture were washed twice with deionized water and resuspended in sterile deionized water to give an appropriate density.

\section{Cellophane Film and Assay Methods}

The cellophane film of $30 \mu$ thickness (PT500, Tokyo cellophane Co., Ltd.) was washed with boiling deionized water over $30 \mathrm{~min}$, dried and used for the experiments. A piece of filter paper, $15 \mathrm{~mm}$ square, was sufficiently impregnated with a test fungicide in fresh rice 
leaf homogenate diluted 100 times $(\mathrm{v} / \mathrm{v})$ with $\mathrm{m} / 100$ phosphate buffer ( $\mathrm{pH} 5.6)$ and placed in a watchglass of $30 \mathrm{~mm}$ diameter. A cellophane piece of $15 \mathrm{~mm}$ square was put on the filter paper piece with forceps. Then the cellophane piece was sprayed with spore suspension and placed in a moist chamber at $25^{\circ} \mathrm{C}$. After incubation for $45 \mathrm{hr}$, the cellophane piece was transferred onto a slide glass and stained with a few drops of dilute zinc chloriodide reagent specially prescribed before, ${ }^{5)}$ and the number of the fungal penetration into the film was counted under a microscope. The points of penetration appeared in halo zones where cellophane was not stained due to the denaturation of cellulose, probably by the cellulose secreted by the penetrating fungus.

\section{Host or Host Tissue and Assay Methods}

Rice seedlings (cultivar Kimmaze) of 5leaf stage grown in a porous pot were used to examine the disease-control activity of fungicides. Three pots, each pot with 10 seedlings, were used for each test plot. The spore suspension containing a given amount of fungicide was sprayed onto the seedlings and kept in a moist chamber at $25^{\circ} \mathrm{C}$. After incubation for 4 days, the number of blast lesions on leaf blades was counted.

Rice leaf sheath was also used to compare with cellophane film. Inner epidermal tissue of the sheath of about $5 \mathrm{~cm}$ long was inoculated with a mixture of spore and fungicide by Sakamoto's method, ${ }^{8)}$ and then incubated in a moist condition at $25^{\circ} \mathrm{C}$ for $45 \mathrm{hr}$. More than
500 appressoria were observed whether penetration occurred or not.

\section{Fungicides}

PCBA (wp, 50\%), tetrachlorophthalide (wp, $50 \%$ ), kasugamycin (wp, 2\%), S-benzyl diisopropyl phosphorothiolate (IBP, ec, 48\%), and diisopropyl 1,3-dithiolan-2-ylidenemalonate (isoprothiolane, ec, $40 \%$ ) were used. Phenylthiourea was also tested because of its characteristic activity. ${ }^{9}$

\section{RESULTS}

\section{Disease-control Activity of Fungicides}

The fungus is directly in contact with a test compound in the ordinary evaluation system in vitro. In order to compare the results in vitro with those in vivo, the spore suspension directly mixed with a fungicide was sprayed on rice plant. Disease-control activity of fungicides is shown in Table 1.

During the blast-lesion development, the fungus should proceed on its infection process such as spore germination, appressorium formation, penetration into host cells, and mycelial growth in host tissues. Inhibitory effects of fungicides on each developmental stage except the penetration stage are cited from references to compare with the present result (Table 1). In vitro fungitoxicity of kasugamycin and IBP seemed to be relevant to their disease-control activity. For other fungicides, however, there were great differences in the effective concentration between in vitro and in vivo.

Table 1 Inhibitory effects of fungicides on different developmental stages of P. oryzae and on disease development.

\begin{tabular}{|c|c|c|c|c|c|}
\hline \multirow[b]{2}{*}{ Fungicide } & \multicolumn{4}{|c|}{$\mathrm{ED}_{95}$ in $\mu \mathrm{g} / \mathrm{ml}$ for } & \multirow[b]{2}{*}{ Reference } \\
\hline & $\underset{\text { growth }^{\text {a) }}}{\text { Mycelium }}$ & $\begin{array}{c}\text { Spore } \\
\left.\text { germination }^{a}\right)\end{array}$ & $\underset{\text { formation }^{\mathrm{a}}}{\text { Appressorium }}$ & $\begin{array}{c}\text { Disease } \\
\text { development }\end{array}$ & \\
\hline PCBA & $1,000<$ & $1,000<$ & $300<$ & $5-10$ & ( 2$)$ \\
\hline Tetrachlorophthalide & $1,000<$ & $1,000<$ & $1,000<$ & $5-10$ & ( 3$)$ \\
\hline Kasugamycin & $<1$ & $200<$ & $40<$ & $2-5$ & (10) \\
\hline IBP & $<10$ & 20 & - & $10-30$ & $(11)$ \\
\hline Isoprothiolane & 40 & 200 & 50 & $1-5$ & ( 5$)$ \\
\hline Phenylthiourea & $1,000<$ & $1,000<$ & $1,000<$ & $100-200$ & ( 9 ) \\
\hline
\end{tabular}

a) These values are cited from the respective references.

b) Expressed by concentrations where $95 \%$ of the blast lesions was inhibited when fungicides were applied on rice seedlings by mixing with conidiospores of $P$. oryzae. Values show the fluctuation range in four experiments. 
2. Effects of Fungicides on the Penetration Stage of P. oryzae

Frequency of spore germination, appressorium formation, and appressorial penetration on/into cellophane film reached maximum 5, 20 , and $45 \mathrm{hr}$ after inoculation, respectively. More appressoria were formed under the modified condition in the present experiment than in the previous one. ${ }^{5)}$ Appressorial or hyphal penetration was easily distinguishable each other under a microscope (Fig. 1). Growth of hyphae penetrated was limited within the film as previously reported. ${ }^{5}$ Penetration frequency was microscopically counted by haloes. Inhibitory effects of fungicides on different penetrations into cellophane film and on appressorial penetration into rice-sheath cells by $P$. oryzae are shown in Table 2 .

Neither spore germination nor appressorium formation was inhibited by fungicides at the present test concentrations except for IBP at $10 \mu \mathrm{g} / \mathrm{ml}$ where germination rate was low and
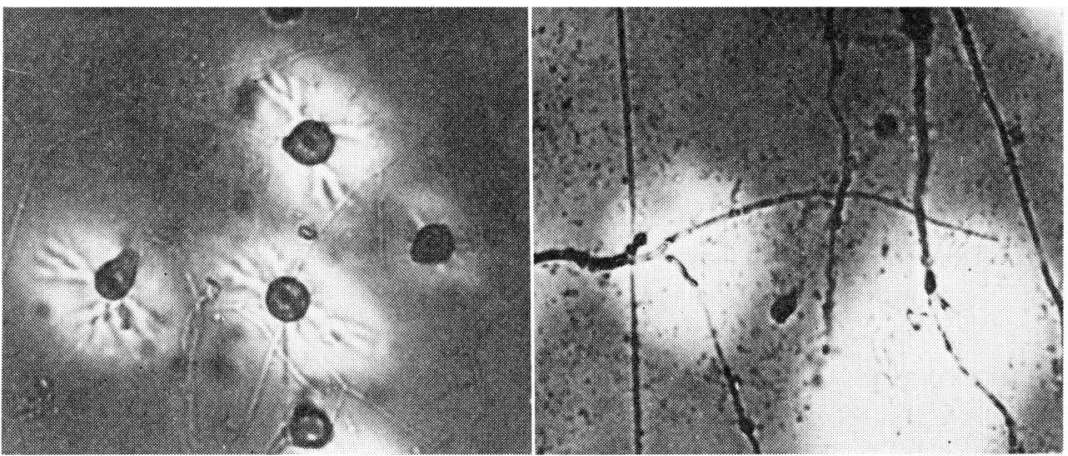

Fig. 1 Appressorial (left) and hyphal (right) penetration by $P$. oryzae observed on a cellophane film. Negative reaction (halo zone) to cellulose staining reagent appeared at the sites of penetration.

Table 2 Inhibitory effects of fungicides on two modes of penetration by P. oryzae.

\begin{tabular}{|c|c|c|c|c|}
\hline \multirow{3}{*}{ Fungicide } & \multirow{3}{*}{$\mu \mathrm{g} / \mathrm{ml}$} & \multicolumn{3}{|c|}{ Inhibition $(\%)$} \\
\hline & & \multicolumn{2}{|c|}{ Cellophane film } & \multirow{2}{*}{$\begin{array}{c}\text { Rice sheath } \\
\text { Appressorial } \\
\text { penetration }\end{array}$} \\
\hline & & $\begin{array}{l}\text { Appressorial } \\
\text { penetration }\end{array}$ & $\begin{array}{c}\text { Hyphal } \\
\text { penetration }\end{array}$ & \\
\hline \multirow{3}{*}{ PCBA } & 50 & 100 & 61 & 100 \\
\hline & 4 & 86 & 19 & 92 \\
\hline & 0.5 & 63 & 0 & 52 \\
\hline \multirow{3}{*}{$\begin{array}{l}\text { Tetrachloro- } \\
\text { phthalide }\end{array}$} & 50 & 97 & 0 & 100 \\
\hline & 4 & 91 & 0 & 93 \\
\hline & 0.5 & 87 & 0 & 86 \\
\hline \multirow{3}{*}{ IBP } & 10 & -a) & - ${ }^{\text {a) }}$ & -a) \\
\hline & 2 & 97 & 83 & 85 \\
\hline & 0.5 & 31 & 71 & 47 \\
\hline \multirow{3}{*}{ Isoprothiolane } & 10 & 100 & 100 & 100 \\
\hline & 2 & 100 & 91 & 92 \\
\hline & 0.5 & 91 & 50 & 69 \\
\hline \multirow{3}{*}{ Phenylthiourea } & 100 & 99 & 100 & 97 \\
\hline & 25 & 80 & 69 & 63 \\
\hline & 5 & 0 & 26 & 0 \\
\hline
\end{tabular}

The results are the mean of four replicates.

a) Germination rate was low and no appressorium was formed, 
no appressorium was formed. A significant point in the result in Table 2 is that tetrachlorophthalide selectively inhibited appressorial penetration. The rate of inhibition by PCBA was higher for appressorial penetration than for hyphal one. IBP, isoprothiolane, and phenylthiourea inhibited both types of penetration. Compared with the results on rice sheath where no hyphal penetration occurred, inhibitory effect on appressorial one into the film was in good accordance for all fungicides tested.

\section{DISCUSSION}

If the infection process of a fungus could take place in vitro, it should be very useful for studying direct effects of fungicides on the different stages of the fungus free from influence of a host plant, e.g., phytoalexin production. Of the infection stages of P. oryzae, only the penetration has never been successfully reproduced in vitro.

In the present experiment, although it has not clearly been known which factor favors appressorium formation, ${ }^{12}$ ) the employment of dry cellophane film and spraying-inoculation resulted in increased appressorium formation and appressorial penetration.

Hyphal penetration was observed on cellophane film but not on rice plant, while appressorial penetration was observed in either case. Moreover, selective inhibition of appressorial penetration by tetrachlorophthalide and PCBA was confirmed. These results suggest that only appressorial penetration is a relevant mode of penetration of $P$. oryzae and assaying fungitoxicity of fungicides on the penetration should be done on appressorial one when the cellophane method is employed.

Because of great differences in the effective concentration of fungicides between in vitro and in vivo as shown in Table 1, the efficacy in vivo has been frequently attributed to fungicide's induction of host resistance such as increased peroxidase activity, ${ }^{9)}$ enhanced metabolism of phenolics ${ }^{13)}$ and others unknown. ${ }^{1,3,10,14)}$ Although such effects may be involved in disease-control activities of fungicides, the present results show that the great differences would not remain in terms of effective concentration between in vitro and in vivo if the effects of fungicides were assayed on appressorial penetration in addition to conventional evaluation. Thus, the improved cellophane method supplies important informations useful to explain the disease-control activities of fungicides.

Recently some metabolic changes have been reported during the differentiation of germ tubes into appressoria in rust fungus, ${ }^{15)} \mathrm{Col}$ letotrichum lagenarium, ${ }^{16)}$ and $P$. oryzae. ${ }^{17)}$ These findings seem to emphasize the necessity for assaying fungitoxicity of chemicals on each morphogenetical stage of a fungus in its infection process.

\section{要約}

イネいもち病に有効な数種殺菌剤のいもち病菌の侵入 に対する影響を，セロファン膜を用いて検討した．植物 細胞壁のモデルとして用いたセロフォン膜上で，いもち 病菌胞子は発芽し, 宿主上と同様に付着器から侵入系に よって膜内に侵入した (付着器侵入) が, 付着器を形成 しないで侵入する（菌糸侵入）ものも観察された。この ように異なった 2 種の侵入様式に対して同程度に阻止す る薬郕もあったが，ある薬剤は菌系侵入をまったく阻止 せず，付着器侵入を特異的に阻止した。この薬剤につい ては, 胞子発芽, 付着器形成拉よび菌系生育のいずれに 対しても影響のないことがすでに知られている。 In vitro で検討された抗菌力のうち付着器侵入阻止力が, いずれの薬剤の場合にも，葉鞘検定による結果と有効濃 度の点でよく一致して打り，防除効果を説明しうるよう であった。

\section{REFERENCES}

1) T. Ishiyama \& K. Sato: Jubilee Publication in Commemoration of 60th Birthday of Professor M. Sakamoto, 251 (1968)

2) H. Sumi, Y. Takahi \& Y. Kondo: Ann. Phytopath. Soc. Japan 30, 112 (1965)

3) K. Nambu: Japan Pestic. Inform. 10, 73 (1971)

4) H. Oku \& H. Sumi: Ann. Phytopath. Soc. Japan 34, 250 (1968)

5) F. Araki \& Y. Miyagi: ibid. 42, 401 (1976)

6) Y. Homma, T. Nakajima, T. Shida \& T. Misato: ibid. 39, 338 (1973)

7) T. Watanabe \& T. Sekizawa: ibid. 40, 226 (1974)

8) M. Sakamoto: Bull. Inst. Agr. Res. Tohoku Univ. Japan 1, 120 (1949)

9) N. Matsuyama \& T, Yamaguchi; Ann, 
Phytopath. Soc. Japan 41, 243 (1975)

10) H. Okamoto: Japan Pestic. Inform 10, 66 (1971)

11) E. Yoshinaga \& H. Yamamoto: ibid. 10, $69(1971)$

12) IR. W. Emmet: Ann. Rev. Phytopath. 13, 147 (1975)

13) P. Langcake \& S. G. A. Wickins: J. Gen. Microbiol. 88, 295 (1975)
14) J. D. Froyd, C. J. Paget, L. R. Guse, B. A. Dreikorn \& J. L. Pafford: Phytopathology 66, 1135 (1976)

15) L. Ramakrishnan \& R. C. Staples: ibid. 60, $1087(1970)$

16) M. Tani, N. Ishida \& I. Furusawa: Can. J. Microbiol. 23, 626 (1977)

17) M. Mayama \& M. Yamamoto: Ann. Phytopath. Soc. Japan 43, 314 (1977) 